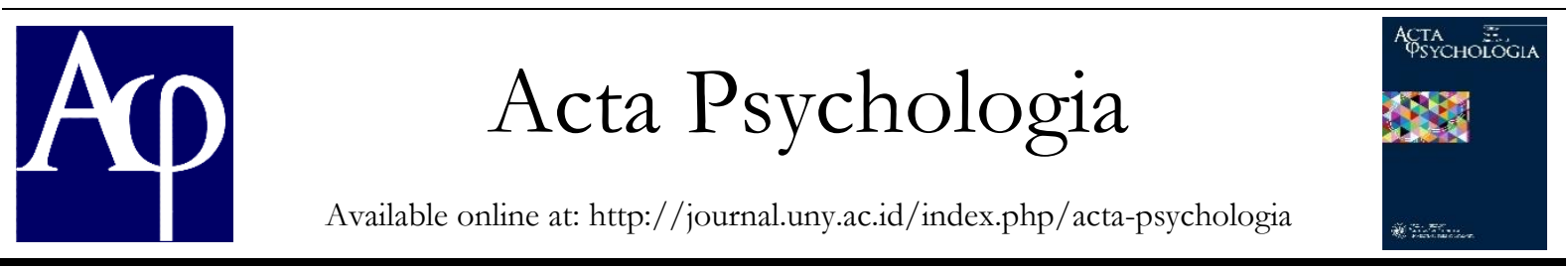

\title{
Strategi Coping pada Mahasiswa yang Sudah Menikah
}

\author{
Hamzah Zulfikar, Siti Rohmah Nurbayati ${ }^{2}$ \\ Jurusan Psikologi, Fakultas Ilmu Pendidikan, Universitas Negeri Yogyakarta; \\ Jl. Colombo No. 1 Sleman Yogyakarta, 55281 \\ pesanhamzah@gmail.com ${ }^{1}$
}

\begin{abstract}
Abstrak
Penelitian ini bertujuan untuk mengkaji dan mendeskripsikan permasalahan yang terjadi pada mahasiswa yang sudah menikah dan strategi coping yang dilakukannya. Penelitian ini menggunakan pendekatan kualitatif dan menggunakan teknik purposive sampling. Kriteria subjek adalah mahasiswa yang sudah menikah dengan minimal usia pernikahan satu semester (6 bulan). Pengumpulan data penelitian dilakukan dengan cara interview. Instrumen dalam penelitian ini yaitu peneliti sendiri dengan dibantu pedoman wawancara dan alat perekam suara. Uji keabsahan data dilakukan dengan member checking dan triangulasi data. Teknik analisis data menggunakan pendekatan kualitatif deskriptif. Hasil penelitian menunjukkan bahwa permasalahan-permasalahan yang muncul pada mahasiswa yang sudah menikah adalah masalah kekhawatiran, keturunan, dan masalah ekonomi. Dari masalah-masalah tersebut, strategi coping yang digunakan adalah problem-focused coping, emotionalfocused Coping, dan Strategi religious-focused coping.
\end{abstract}

Kata Kunci: mahasiswa sudah menikah, strategi coping

\begin{abstract}
This study aims to examine and describe the problems that occur in married students and their coping strategies. This research used a qualitative approach and purposive sampling technique. The subject's criteria were the married students with at least one semester (6 months) of marriage. The data were collected by interview. The instrument in this study was the researcher himself, assisted by an interview guide and voice recorder. The data validity test was done through member checking and data triangulation. The data were analyzed using descriptive qualitative approach. The results showed that the problems that arose among married students were worries, heredity, and economic problems. From these problems, the coping strategies they used were problem-focused coping, emotional-focused coping, and religious-focused coping strategies.
\end{abstract}

Keywords: married students, coping strategy

\section{Pendahuluan}

Menikah pada saat masih menempuh pendidikan di bangku sekolah masih menjadi perdebatan di Indonesia walaupun sekarang ini banyak anak-anak yang masih duduk di bangku sekolah yang sudah melakukan pernikahan dan memilih untuk berhenti sekolah. Lain halnya bagi mereka yang menikah pada saat menempuh pendidikan di perguruan tinggi, mereka sudah diperbolehkan melakukan pernikahan walaupun mereka masih menyandang status sebagai mahasiswa. 
Mahasiswa yang memutuskan untuk menikah pada saat masih menempuh pendidikan di jenjang perguruan tinggi yaitu karena mereka merasa sudah siap dan sudah cukup matang untuk membina rumah tangga karena pada umumnya mereka sudah mencapai umur 18 tahun keatas (Habibahi, Aisyiyah, \& Ningrum, 2012).

Pernikahan adalah ikatan lahir batin antara seorang pria dan seorang wanita sebagai suami istri dengan tujuan membentuk keluarga (rumah tangga) yang bahagia dan kekal berdasarkan Ketuhanan Yang Maha Esa (UU No. 1 tahun 1974). Batasan usia pernikahan di Indonesia menurut Undang-Undang No. 1 tahun 1974 ayat 1, pernikahan dapat dilakukan apabila pihak perempuan minimal berusia 16 tahun dan pihak laki-laki berusia minimal 19 tahun.

Bagi mahasiswa yang memutuskan untuk berkeluarga harus siap dengan tanggung jawab ganda yang akan terjadi pada dirinya, dimana mereka harus membagi waktu antara kuliah dengan keluarga. Selain berkewajiban untuk menyelesaikan kuliahnya, mereka sudah berkeluarga dituntut untuk mencari nafkah dan mengurus keluarganya (Sari \& Nurwidawati, 2013).

Peneliti melakukan wawancara pada beberapa mahasiswa yang sudah menikah dan mereka mengatakan ada banyak kekagetan setelah menikah. Banyak hal-hal yang belum dibayangkan terjadi, tuntutan-tuntutan sosial, moral, ekonomi yang belum dipersiapkan. Peneliti juga mendapatkan data dimana pada tahun 2014 di UNY terdapat mahasiswi dari FT menikah pada saat ia berada di semester 3, sedangkan ia belum mempersiapkan diri secara matang tentang pernikahan. Kemudian di semester berikutnya mahasiswi tersebut mengorbankan perannya sebagai istri dan bercerai dengan suaminya (Wawancara, 7 Oktober 2019).
Peneliti juga melakukan wawancara pada salah satu alumni UNY yang dulu melakukan pernikahan ketika menginjak semester 6 di FIP, ia mengatakan sudah mengetahui konsekuensi dari pernikahan di masa sebagai mahasiswa. Ia juga mengatakan dampak dari pernikahan secara langsung adalah pembagian waktu dari yang fleksibel ketika masih bujang menjadi tidak lagi se-fleksibel itu, apalagi ketika memiliki anak (Wawancara, 8 Oktober 2019). Sehingga dari waktu yang terbagi akan berdampak juga pada waktu masa studi kuliahnya. Subjek memerlukan waktu 14 semester untuk menyelesaikan studi dan bisa disebut terlambat lama karena idealnya mahasiswa selesai studi pada semester 8 .

Mampu untuk menentukan prioritas merupakan hal penting bagi mahasiswa yang sudah berkeluarga karena dari hasil penelitian yang dilakukan oleh Afrida (2017) menunjukkan bahwa konflik yang dialami oleh mahasiswa yang sudah berkeluarga yaitu time based conflict, yaitu konflik tidak seimbangnya pembagian waktu antar peran. Waktu untuk pemenuhan suatu peran dapat mengurangi waktu untuk memenuhi peran yang lainnya sehingga membuat kerugian pada peran yang lain karena waktu yang digunakan kurang dan dapat menjadi permasalahan di dalam kehidupan mahasiswa yang sudah berkeluarga.

Hasil penelitian yang dilakukan oleh Habibahi, Aisyiyah, dan Ningrum (2012) menunjukkan bahwa status perkawinan bagi mahasiswa dapat mempengaruhi prestasi akademik yang diraih baik dilihat dari proses perkuliahan maupun indeks prestasi yang diperoleh karena bertambahnya beban bagi mahasiswa yang sudah berkeluarga. Mahasiswa yang sudah berkeluarga sering terlambat masuk kelas perkuliahan karena alasan mereka mengurus keluarga terlebih dahulu sebelum berangkat kuliah dan frekuensi kehadiran perkuliahan mereka 
menurun. Selain itu mahasiswa yang sudah berkeluarga juga mengalami permasalahan dalam penyelesaian tugas kuliah, mereka merasa terhambat dalam menyelesaikan tugas kuliah dan sering tidak ikut mengerjakan tugas kelompok karena mereka juga harus membagi waktunya dengan tugas-tugas rumah tangga, sehingga menyebabkan indeks prestasi sebelum dan sesudah menikah rata-rata mengalami penurunan.

Hasil penelitian yang dilakukan oleh Sari dan Nurwidawati (2013) menunjukkan bahwa permasalahan yang sering muncul dalam kehidupan pernikahan mahasiswa ialah sulit untuk menyesuaikan diri dengan pasangan karena selain menyesuaikan diri dengan pasangan juga harus membagi waktu untuk menyesuaikan diri dengan keluarga pasangannya, penyesuaian diri dengan peran sebagai orang tua, dan penyesuaian diri dengan waktu untuk kuliah.

Berbeda dari yang lain, penelitian yang dilakukan oleh Rohman (2010) tentang "implikasi pernikahan pada masa studi terhadap prestasi belajar" menghasilkan (1) perkembangan hasil prestasi yang diraih setelah menikah tidak ada yang menurun, tapi setidaknya tetap bertahan bahkan semakin meningkat, (2) perkembangan keaktifan dalam mengikuti perkuliahan setelah menikah bervariasi, ada yang semakin aktif, menurun, sama-sama aktif, dan ada yang sama-sama sering bolos kuliah baik sebelum maupun sesudah menikah, (3) pernikahan dapat mempengaruhi studi dalam tiga hal yaitu motivasi, keaktifan, dan perubahan gaya belajar, (4) pernikahan tidak berimplikasi secara langsung terhadap prestasi yang diraih, akan tetapi pernikahan berpengaruh terhadap beberapa faktor keefektifan belajar yang pada akhirnya baru dapat mempengaruhi prestasi belajar yang akan diraih.
Memiliki dua peran yaitu menjadi mahasiswa dan menjadi seorang istri atau suami tentu menjadi tidak mudah untuk bisa menyeimbangkan porsi kedua peran tersebut. Menurut Vaez dan Juhari (2017) sulit untuk mendapatkan keseimbangan antara pendidikan dan kehidupan perkawinan karena membutuhkan banyak usaha dan perhatian dari kedua pasangan. Oleh karena itu stres dapat menjadi faktor resiko yang menonjol dari pendidikan dan kehidupan pernikahan

Menurut Kholidah dan Alsa (2012), kebanyakan mahasiswa mengalami stres karena adanya tuntutan akademik untuk memahami materi yang banyak dengan intensitas waktu yang relatif sedikit. Selain itu adanya ujian dengan banyaknya materi yang diujikan juga dapat menyebabkan stres tinggi bagi mahasiswa. Menurut Aswati (2017) bagi mahasiswa yang sudah berkeluarga kehidupannya pun otomatis berubah dan menjadi memiliki peran ganda. Beban berat yang diberikan oleh peran ganda tersebut dapat menjadi sumber stres bagi para mahasiswa yang sudah menikah.

Menurut Lazarus (dalam Carver, Weintraub, \& Scheier, 1989), saat menghadapi stres individu akan berusaha memilih satu respon dari berbagai alternatif respon yang dimilikinya dan berupaya menjalankannya. Upaya individu dalam menghadapi situasi yang menimbulkan stres disebut coping. Dalam menghadapi tuntutan eksternal maupun internal dalam suatu situasi yang menimbulkan stres, individu memiliki dua alternatif pilihan coping, yakni problem-focused coping dan emotion-focused coping (Lazarus \& Folkman dalam Carver, Weintraub \& Scheier, 1989). Problem-focused coping merupakan tindakan langsung untuk menyelesaikan masalah ataupun mencari informasi yang relevan dengan solusi, sementara emotion-focused coping merupakan usaha untuk mengurangi reaksi emosional negatif yang ditimbulkan oleh stres. 


\section{Metode Penelitian}

Jenis Penelitian

Penelitian yang berjudul Strategi Coping pada Mahasiswa yang Sudah Menikah ini menggunakan pendekatan kualitatif dengan metode deskriptif naratif.

\section{Waktu dan Tempat Penelitian}

Penelitian ini dilaksanakan di

Daerah Istimewa Yogyakarta, pada 13 Desember 2019 hingga 18 Februari 2020.

\section{Target/Subjek Penelitian}

Responden atau subjek pada penelitian ini merupakan mahasiswa aktif jenjang S-1. Pemilihan subjek menggunakan teknik pengambilan dengan sampel non probabilitas (non probability sampling) dengan jenis purposive sampling. Berikut karateristik informan dalam penelitian ini:

1. Berstatus mahasiswa yang dibuktikan dengan adanya KTM atau KRS.

2. Berstatus menikah yang dibuktikan dengan adanya buku nikah.

3. Bersedia menjadi subjek penelitian dengan mengisi informed consent.

\section{Teknik Pengumpulan Data}

Dalam penelitian ini, metode wawancara digunakan sebagai teknik pengumpul data utama. Instrumen pengumpulan data yang digunakan, yaitu berupa pedoman wawancara. Wawancara akan direkam, rekaman wawancara ini digunakan untuk membantu peneliti mengidentifikasi bagian-bagian dari penelitian yang ditemukan selama wawancara atau data sebelumnya serta melaporkan berbagai catatan yang didapat selama wawancara.

\section{Teknik Analisis Data}

Teknik analisis data yang digunakan oleh peneliti adalah pendekatan kualitatif dengan metode IPA (Interpretative Phenomenological Analysis). Data yang diperoleh dari penelitian ini melalui wawancara dan kuesioner terbuka akan dianalisis dengan langkah-langkah berikut:

\section{Pengumpulan Data}

Tahap pengumpulan data yang dilakukan oleh peneliti adalah menggunakan metode wawancara dan kuesioner terbuka. Sebelum melakukan pengumpulan data peneliti terlebih dahulu menghubungi dan menemui setiap responden untuk memberikan informed consent. Setelah memberikan informed consent peneliti melakukan wawancara yang bertujuan untuk memperoleh data dari responden di tempat dan waktu yang sudah ditetapkan.

\section{Reduksi Data}

Mengolah dan mempersiapkan data untuk dianalisis. Pada tahap ini peneliti mengubah file rekaman ke dalam bentuk teks, yang termasuk di dalamnya adalah transkripsi wawancara, men-scanning materi, mengetik data lapangan, kuesioner, atau memilah-milah dan menyusun data tersebut ke dalam jenis-jenis yang berbeda tergantung pada sumber informasi.

\section{Display Data}

Pada tahap display data, data setengah jadi yang sudah diolah dalam bentuk tulisan dan sudah memiliki alur tema yang jelas selanjutnya dimasukkan ke dalam matriks kategorisasi. Matriks kategorisasi berisi kategori tema yang kemudian dipecah dalam bentuk subkategori tema yang lebih konkret dan sederhana serta diakhiri dengan pemberian kode (coding) dari sub-kategori tema tersebut.

\section{Kesimpulan/Verifikasi}

Dalam tahap kesimpulan teknik analisis data kualitatif model interaktif terdapat tiga langkah yang perlu dilakukan, antara lain menguraikan sub-kategori tema dalam tabel kategorisasi dan koding disertai quote verbatim wawancaranya, selanjutnya menjelaskan hasil temuan penelitian dengan menjawab pertanyaan penelitian 
berdasarkan aspek/dimensi/komponen dari central phenomenon, yaitu strategi coping, dan terakhir membuat kesimpulan dengan memberikan penjelasan kesimpulan dari jawaban pertanyaan penelitian yang diajukan.

\section{Hasil Penelitian dan Pembahasan}

Berdasarkan hasil penelitian yang telah dilakukan oleh peneliti, keempat subjek memiliki berbagai masalah, yaitu masalah merasa khawatir/takut, masalah relasi, masalah dengan pernikahan itu sendiri, masalah keturunan, masalah akademik, masalah keuangan/ekonomi, dan stres.

Permasalahan yang muncul pada keempat subjek memiliki kesamaan berupa masalah dalam relasi dan masalah dengan pernikahan. Kemudian ada masalah kekhawatiran dan masalah akademik yang hanya muncul pada subjek AF, masalah stres yang muncul pada subek AF dan DW, masalah ekonomi atau keuangan pada subjek DW dan DV, serta masalah keturunan pada subjek AF dan UT.

Menurut Kaplan, Sadock, dan Grebb (dalam Fauziah \& Widuri, 2007) kecemasan adalah respon terhadap situasi tertentu yang mengancam, dan merupakan hal yang normal terjadi menyertai perkembangan, perubahan, pengalaman baru atau yang belum pernah dilakukan, serta dalam menemukan identitas diri dan arti hidup. Pernyataan tersebut sesuai dengan apa yang dialami oleh subjek yang merasakan khawatir terhadap berbagai hal dalam menjadi mahasiswa yang sudah menikah yang belum pernah ia jalani sebelumnya.

\section{Soerjono Soekanto} menyebutkan beberapa penyebab konflik yang terjadi dalam masyarakat antara lain perbedaan antara individu-individu, perbedaan kebudayaan, perbedaan kepentingan, dan perubahan sosial.
Beberapa faktor penyebab konflik yang telah disebutkan diatas dapat menjadi pemicu konflik relasi yang terjadi dalam kehidupan mahasiswa yang sudah menikah. Subjek penelitian juga menyebutkan permasalahan dalam relasi yang sesuai dengan pernyataan tersebut.

Masalah dengan pernikahan yang muncul di penelitian ini berupa hal-hal yang tidak bisa dilakukan atau dilanjutkan karena subjek sudah menikah. Contohnya mimpi-mipi di masa lajang seperti lanjut studi S2 dimatikan dan lebih prioritas ke keluarga dan anak, atau tidak bisa mengikuti ajang duta bahasa dan duta pendidikan karena syarat untuk mengikutinya adalah masih lajang.

Masalah akademik yang muncul pada salah satu subjek penelitian adalah masalah Tugas Akhir Skripsi yang tidak segera diselesaikan, hal sini dikarenakan subjek memiliki tanggung jawab baru sebagai seorang suami dan harus bekerja untuk memberikan nafkah kepada keluarganya. Ia pun kini dikaruniai seorang anak sehingga menyebabkan tugas akhir skripsi sebagai syarat kelulusan studi S1 terlupakan.

Menurut Chen dan Volpe (1998), literasi keuangan adalah pengetahuan untuk mengelola keuangan dalam pengambilan keputusan keuangan. Pengetahuan keuangan meliputi: pengetahuan umum keuangan pribadi, tabungan dan pinjaman, asuransi, dan investasi. Berdasarkan teori tersebut masalah yang muncul pada subjek penelitian dalam keuangan disebabkan karena kurangnya literasi keuangan sehingga muncul masalah seperti tidak ada tabungan dan juga kesulitan ketika menyambut masa pembayaran biaya pendidikan.

Sarafino (2006) mendefinisikan stres adalah kondisi yang disebabkan oleh ineraksi antara individu dengan lingkungan, 
menimbulkan persepsi jarak antara tuntutan-tuntutan yang berasal dari situasi yang bersumber pada sistem biologis, psikologis, dan sosial dari seseorang. Ardani (2007) mendefinisikan stres merupakan suatu keadaan tertekan baik itu secara fisik maupun psikologis.

Tabel 1. Masalah yang Muncul dan Strategi Penyelesaian

\begin{tabular}{lcccc}
\hline Masalah yang Muncul & A & D & U & D \\
& F & W & T & V \\
\hline Kekhawatiran/ketakutan & $\checkmark$ & & & \\
Masalah dalam Relasi & $\checkmark$ & $\checkmark$ & $\checkmark$ & $\checkmark$ \\
Masalah Akademik & $\checkmark$ & & & \\
Masalah dengan & & & & \\
$\begin{array}{l}\text { Pernikahan } \\
\text { Masalah Keinginan yang }\end{array}$ & & & & $\checkmark$ \\
Terhambat & & $\checkmark$ & & \\
Masalah & & & & \\
$\begin{array}{l}\text { Ekonomi/Keuangan } \\
\text { Masalah keturunan }\end{array}$ & & $\checkmark$ & & $\checkmark$ \\
Stres & $\checkmark$ & & $\checkmark$ & \\
& $\checkmark$ & $\checkmark$ & & \\
\hline
\end{tabular}

Tabel 2. Strategi Penyelesaian Masalah

\begin{tabular}{|c|c|c|c|c|}
\hline $\begin{array}{c}\text { Strategi Penyelesaian } \\
\text { Masalah }\end{array}$ & $\begin{array}{l}\mathbf{A} \\
\mathbf{F}\end{array}$ & $\begin{array}{l}\mathrm{D} \\
\mathbf{W}\end{array}$ & $\begin{array}{l}\mathbf{U} \\
\mathbf{T}\end{array}$ & $\begin{array}{l}\mathrm{D} \\
\mathrm{V}\end{array}$ \\
\hline Mencari informasi, & & & & \\
\hline $\begin{array}{l}\text { nasehat, atau dukungan } \\
\text { dari orang lain }\end{array}$ & $\checkmark$ & & & $\checkmark$ \\
\hline $\begin{array}{l}\text { Menghindari dan } \\
\text { melupakan masalah }\end{array}$ & $\checkmark$ & & & \\
\hline $\begin{array}{l}\text { Mencari dukungan } \\
\text { emosional }\end{array}$ & $\checkmark$ & & & \\
\hline $\begin{array}{l}\text { Melakukan ritual } \\
\text { keagamaan }\end{array}$ & $\checkmark$ & $\checkmark$ & & \\
\hline Mengendalikan diri & $\checkmark$ & $\checkmark$ & & \\
\hline $\begin{array}{l}\text { Membentuk langkah- } \\
\text { langkah penyelesaian }\end{array}$ & $\checkmark$ & & $\checkmark$ & $\checkmark$ \\
\hline $\begin{array}{l}\text { Menyelesaikan secara } \\
\text { langsung }\end{array}$ & $\checkmark$ & $\checkmark$ & $\checkmark$ & $\checkmark$ \\
\hline $\begin{array}{l}\text { Menerima situasi seraya } \\
\text { mencari solusi }\end{array}$ & $\checkmark$ & & $\checkmark$ & \\
\hline $\begin{array}{l}\text { Memandang dari sudut } \\
\text { positif masalah }\end{array}$ & $\checkmark$ & & & \\
\hline Mengabaikan & & $\checkmark$ & & $\checkmark$ \\
\hline $\begin{array}{l}\text { Mencari makna dari } \\
\text { masalah }\end{array}$ & & & $\checkmark$ & \\
\hline
\end{tabular}

Masing-masing subjek memiliki permasalahan yang berbeda-beda dan tentu saja memiliki cara penyelesaian yang berbeda-beda. Hal ini dikarenakan masingmasing memiliki latar belakang yang berbeda-beda. Seperti AF yang menjadi subjek laki-laki satu-satunya dalam penelitian ini, sehingga ia memiliki peran sebagai suami. Ia juga satu-satunya yang sudah memiliki anak, sehingga tentu saja berbeda permasalahan dan penyelesaiannya dengan subjek yang lain.

Kemudian DW yang menikah dengan orang Makassar yang memiliki budaya dan watak yang sangat berbeda dengan orang Jawa, kemudian ia satusatunya yang LDR dengan suami berbeda pulau. Hal ini juga menjadikannya memiliki masalah dan cara penyelesaian yang khas.

UT memiliki masalah yang berbeda juga di mana ia tinggal bersama suaminya yang rumahnya berdekatan dengan keluarganya. Selain itu, mayoritas di daerah tempat tinggal suaminya afiliasi ke NU dan tempat asal UT adalah Muhammadiyah. Hal tersebut pun memunculkan masalah yang khas.

Subjek DV memiliki latar belakang broken home, orang tuanya bercerai dan sudah memiliki keluarga sendiri-sendiri. Ia juga merantau sendiri ke Jawa pada masa remaja dan berpindah agama, sehingga ia tidak memiliki keluarga sama sekali. Tentulah ini menjadi permasalahan sendiri dan cara penyelesaian yang berbeda.

Perbedaan cara penyelesaian masalah tersebut dapat terjadi dikarenakan faktor-faktor yang memengaruhi seperti yang dikatakan oleh Hapsari, Karyani, \& Taufik (2002) bahwa terdapat beberapa faktor yang memengaruhi penggunaan EFC, yaitu: usia, jenis kelamin, dan kepribadian. Sedangkan faktor-faktor yang memengaruhi PFC terdapat pendapat yang dikemukakan oleh Lazarus dan Folkman (1984) yaitu: kesehatan dan energi, 
keyakinan yang positif, kemampuan pemecahan masalah, keterampilan sosial, dukungan sosial, dan sumber material.

\section{Simpulan dan Saran}

\section{Simpulan}

Berdasarkan pembahasan hasil penelitian dapat ditarik kesimpulan bahwa permasalahan-permasalahan yang muncul pada mahasiswa yang sudah menikah adalah masalah kekhawatiran, masalah dalam relasi, masalah dengan pernikahan, masalah akademik, masalah keturunan dan masalah ekonomi. Strategi coping yang dilakukan oleh mahasiswa yang sudah menikah untuk menyelesaikan permasalahan-permasalahan yang dihadapinya adalah planfull problem solving, emotion focused coping, dan strategi coping berbasis religi.

\section{Saran}

1. Bagi mahasiswa yang memiliki intensi untuk menikah, agar mempersiapkan dengan baik dan matang segala hal dalam menyambut pernikahan semasa menjadi mahasiswa untuk mengantisipasi permasalahanpermasalahan yang muncul dalam kehidupan sebagai mahasiswa yang sudah menikah nantinya.

2. Bagi mahasiswa yang sudah menikah, saat menjumpai suatu permasalahan agar menerapkan strategi coping baik problem focused coping, emotion focused coping, dan/atau strategi coping berbasis religi. Penerapan strategi coping yang tepat diharapkan dapat mengatasi permasalahan-permasalahan yang dialami.

3. Bagi peneliti selanjutnya, penelitian ini dapat digunakan sebagai acuan untuk melakukan penelitian dengan tema yang sama, namun dalam pembahasan aspek yang berbeda. Peneliti selanjutnya juga dapat menggunakan subjek dan metode penelitian yang berbeda agar didapatkan hasil dan pembahasan yang lebih luas mengenai strategi coping. Saran ini ditulis untuk menambahkan wawasan, perbandingan dan penyempurnaan bagi peneliti sebelumnya dan penelitian berikutnya.

\section{Daftar Pustaka}

Afrida, E. N. (2017). Makna konflik peran pada mahasiswa dengan peran ganda. Jurnal Wahana, 68(1). 23-26.

Ardani, T. A. (2007). Psikologi klinis. Yogyakarta : Graha Ilmu.

Aswati. (2017). Konflik peran ganda, rasa cinta dan kepuasan pernikahan pada mahasiswi yang sudah berumah tangga. Jurnal Psikologi, 5(1), 83-93.

Carver, S., Scheier, F. Micheal., \& Weintraub, K. J. (1989). Assesing coping strategies: A theoretically based approach. Journal of Personality and Social Psychology, 56 (2), 267-283.

Chen, H. dan Volpe, R. P. (1998). An analysis of personal financial literacy among college students. Financial Services Review, 7(2), 107128

Fauziah, Fitri dan Julianti Widuri. (2007). Psikologi Klinis Abnormal Dewasa. Jakarta: UI-Press.

Habibahi, U., dkk. (2012). Studi tentang status perkawinan mahasiswa reguler PGSD Tegal bubungannya dengan prestasi akademik. Semarang: Journal of Elementary Education 1. Jurusan PGSD Fakultas Ilmu Pendidikan Universitas Negeri Semarang.

Hapsari, R.A. Karyani, U. \& Taufik. (2002). Perjuangan hidup pengungsi kerusuhan etnis (studi kualitatif tentang bentuk-bentuk 
perilaku coping pada pengungsi di Madura). Indigenous, 6 (2).

Lazarus, R.S \& Folkman, S. (1984). Stress appraisal and coping. New York : Springer Publishing Company.Inc.

Rohman, H. N. (2010). Implikasi pernikahan pada masa studi terbadap prestasi belajar. Skripsi Fakultas Tarbiyah dan Keguruan UIN Sunan Kalijaga Yogyakarta.

Sarafino. E. P. (2006). Health Psychology: Biosychosocial interactions. 5th edition. New York: John Wiley \& Sons . Inc.

Sari \& Nurwidawati. (2013). Studi kasus kehidupan pernikahan mahasiswa. yang menikah saat menempuh masa kuliah. Jurnal Studi Psikologi, 2(2).

Soekanto, S. (2012). Sosiologi suatu pengantar. Jakarta: PT. Rajagrafindo Persada.

Undang-Undang Republik Indonesia Nomor 1 Tahun 1974. Tentang Perkawinan. 